\title{
Gea
}

JURNAL PENDIDIKAN GEOGRAFI

\section{ANALISIS HARGA LAHAN BERDASARKAN CITRA PENGINDERAAN JAUH RESOLUSI TINGGI}

\author{
Iswari Nur Hidayati \\ Fakultas Geografi Universitas Gadjah Mada \\ Email: iswari@geo.ugm.ac.id, No HP : 085729005471
}

\begin{abstract}
Mapping Land Pricesin Yogyakarta is very important because land prices increased rapidlyalong with economic growth. Mapping land prices require some parameters that can be extracted using remote sensing data. There fore, the researc her had the idea to do some researc habout the price of land. in the District Jetis Yogyakarta. Theaims of this research are a). to assess of Quickbird images for land prices mapping, b). to know the spatial distribution of land prices in District Jetis. Remote sensing data could be extracted for land-use data extraction. Land use data were used as input to search for land accessibility of positive and negative land accessibilities. These parameters used to find the estimated price of land. Field data collections were used to compare and support for land pricing data. The results showed that Quickbird satellite imagery can be used to extract the parameters determining the land price with overall accuracy of 92.49\%. The results of the mapping of land prices in the District were divided into four classes Jetis land prices. In the District Jetis most regions belong to high land price classeswas $52.35 \%$. Land prices were very high class had the second largest percentage of 22.94. The third classeswere consisting of $21.76 \%$ and the fourth land price class had also the lowest percentage of $2.75 \%$.
\end{abstract}

Keywords : Land Prices, Remote Sensing Imagery, Mapping.

\begin{abstract}
ABSTRAK
Pemetaan harga lahan di Yogyakarta sangat diperlukan, hal ini dikarenakan kenaikan harga lahan sangat pesat seiring dengan pertumbuhan ekonomi.Pemetaan harga lahan menggunakan parameter yang bisa disadap menggunakan data penginderaan jauh seperti aksesibilitas lahan, penggunaan lahan, dengan aksesibilitas negatif. Oleh karena itu, peneliti mempunyai gagasan untuk melakukan penelitian tentang harga lahan. Adapun tujuan penelitian adalah a) Mengetahui kemampuan citra Quickbird untuk mengetahui tingkat harga lahan, b) Untuk mengetahui distribusi spasial tentang harga lahan di Kecamatan Jetis. Data penginderaan jauh akan digunakan untuk ekstrasi data penggunaan lahan. Penelitian ini terdiri atas tiga tahapan yaitu tahap persiapan, tahap pemrosesan data, dan tahap analisis data. Data penggunaan lahan akan dianalisis lebih lanjut untuk mengetahui aksesibilitas lahan positif dan lahan negative. Beberapa parameter ini digunakan untuk mendukung dalam memetakan harga lahan di Kecamatan Jetis.Untuk menambah informasi, pengumpulan data lapangan sangat diperlukan untuk mendukung pemetaan ini. Hasil dari penelitian ini menunjukkan bahwa citra Quickbird dapat digunakan untuk penelitian ini dengan akurasi pemetaan sebesar 92,49\%. Hasil pemetaan harga lahan ini dibagi menjadi empat kelas dengan kelas harga lahan tertinggi terdapat 52,35\%. Harga lahan tinggi terdapat 22,94\%, kelas lahan sedang terdapat $21,76 \%$, dan kelas lahan rendah mempunyai luasan sekitar 2,75\%.
\end{abstract}

Kata kunci : harga lahan, penginderaan jauh, pemetaan. 


\section{PENDAHULUAN}

Dalam era globalisasi seperti sekarang ini, perkembangan ilmu pengetahuan dan teknologi sangat cepat seiring dengan perkembangan zaman.Perkembangan citra resolusi tinggi merupakan salah satu cerminan dari pesatnya perkembangan teknologi.Citra Quickbird merupakan salah satu citra penginderaan jauh yang memiliki resolusi spasial tinggi yang mampu digunakan untuk analisis perkotaan.Dengan memanfaatkan citra Quickbird untuk interpretasi secara visual maupun digital, data dengan ketelitian yang cukup tinggi bisa didapatkan.

Seperti halnya pemanfaatan citra quickbird untuk aplikasi kajian harga lahan yang mampu menyajikan berbagai faktor untuk estimasi harga lahan di daerah perkotaan. Ektraksi data penggunaan lahan secara detail dapat disadap dari Citra Quickbird tersebut. Pemetaan harga lahan yang terdiri dari beberapa parameter yaitu aksesibilitas lahan, penggunaan lahan, dengan aksesibilitas negatif, merupakan faktor utama untuk penentuan harga lahan suatu daerah. Pemetaan harga lahan akan lebih efektif dan efisien apabila disajikan secara visual sehingga batas masing-masing kawasan dapat diketahui dengan pasti pola keruangan dan posisi absolutnya.

Penyajian untuk harga lahan ini tentunya juga ditentukan oleh faktor yang besifat social yaitu perkembangan penduduk. Kecamatan Jetis, salah satu kecamatan di Yogyakarta mengalami perkembangan yang sangat pesat dalam bidang social ekonominya. Banyaknya sarana pendidikan, instansi pemerintah, maupun swasta, serta didukung oleh perkembangan perdagangan dan jasa, membuat Kecamatan Jetis mengalami perubahan penggunaan lahan yang sangat cepat.Hal ini mendorong masyarakat untuk mencari alternative daerag untuk dijadikan sebagai pusat kegiatan perdagangan, jasa, maupun kegiatan ekonomi lainnya.Oleh karena itu diperlukan suatu kajian tentang harga lahan dengan menggunakan citra resolusi tinggi pada Kecamatan ini, sehingga diharapkan penelitian ini mampu untuk menjawab tantangan tersebut.

Penelitian ini bertujuan: a). Untuk mengkaji kemampuan Citra Quickbird dalam pemetaan harga lahan; b). Mengetahui distribusi spasial harga lahan di Kecamatan Jetis.

\section{METODE PENELITIAN}

\section{Alat dan Bahan yang Digunakan}

Kebutuhan alat dan bahan yang akan digunakan pada penelitian ini sebagai berikut: citra quickbird tahun 2006, data statistik kota Yogyakarta tahun 2010, data kelengkapan utilitas umum kecamatan Jetis, GPS untuk pengeplotan titik sampel lapangan, dan software untuk pemrosesan Sistem Informasi Geografi.

\section{Tahapan Penelitian}

Pernelitian dilakukan ke dalam tiga tahap, yaitu tahap persiapan, tahap pemrosesan data, dan tahap analisis data. Tahapan persiapan yang dilakukan meliputi studi pustaka dan literatur yang berkaitan dengan topik penelitian. Tahapan persiapan ini juga menyiapkan citra IKONOS sebagai data dasar untuk melakukan penelitian sebagai masukan untuk input data. Data-data sekunder juga dipersiapkan sebagai data pendukung dalam penelitian ini.

Tahapan Pemrosesan Data. Input data untuk penelitian berasal dari interpretasi penggunaan lahan secara visual berdasarkan citra IKONOS Kecamatan Jetis. Hasil dari interpretasi penggunaan lahan tersebut kemudian dilakukan analisis berdasarkan parameterparameter penentuan harga lahan yaitu penggunaan lahan itu sendiri, aksesibiltas lahan positif, aksesibilitas lahan negatif, dan kelengkapan fasilitas umum.

Adapun berbagai parameter penentu harga lahan dapat dilihat pada tabel 1.

Tabel 1. Parameter Penentu Harga Lahan 


\begin{tabular}{lll}
\hline No & Parameter Penentu Harga Lahan & Keterangan \\
\hline 1 & Penggunaan Lahan & Perdagangan dan Jasa \\
& & Permukiman dan Industri \\
& & Lahan Kosong \\
& & Sawah dan Tegalan \\
\hline 2 & Aksesibilitas Lahan Positif & Jarak Terhadap Jalan Arteri \\
& & Jarak terhadap Jalan Kolektor \\
& & Jarak terhadap Lembaga Pendidikan \\
\hline 3 & Aksesibilitas Lahan Negatif & Jarak Terhadap Kantor Pemerintahan \\
& & Jarak Terhadap Sungai \\
& & Jarak terhadap Sumber Polusi \\
\hline 4 & Kelengkapan Fasilitas Umum & Jarak terhadap Kuburan \\
& & Jumlah bank pemerintah dan swasta \\
& & Jumlah pasar umum \\
& & Tempat Ibadah \\
& & Jumlah Swalayan \\
& & Jumlah Koperasi \\
& & Pelayanan Kesehatan \\
& Hotel \\
& Wartel \\
\hline
\end{tabular}

Sumber : Hidayati, 2010

Tahapan analisis data. Pada tahapan ini menggunakan skoring (pengharkatan). Hal ini dimaksudkan agar memudahkan dalam melakukan analisis. Pembobotan dilakukan berdasarkan peran masing-masing parameter yang ada.

\section{Klasifikasi Penggunaan Lahan}

Pengetahuan tentang penutup dan penggunaan lahan penting untuk kajian dalam bidang perencanaan dan manajemen, yang dipertimbangkan sebagai elemen penting untuk memodelkan dan mempelajari bumi sebagai suatu sistem (Lillesand et al., 2008). Penutup dan penggunaan lahan merupakan dua hal yang berbeda. Penutup lahan merupakan jenis material yang meliputi kenampakan biofisik yang ada pada permukaan (lahan/ bentanglahan/ bumi) (Jensen, 2005 \& 2007 ; Lillesand et al., 2008 ; Sabins, 1987).Penggunaan lahan merujuk pada bagaimana luasan potongan (parcel) lahan yang digunakan oleh manusia (Jensen, 2005 \& 2007 ; Sabins, 1987) yang ditekankan pada fungsi ekonomisnya (Campbell, 2002 ; Lillesand et al., 2008). Dalam penelitian ini menggunakan sistem klasifikasi USGS Land Use/Land Cover Classification System for Use Remote Sensor Data. Sistem Klasifikasi secara lengkap dapat dilihat dalam skema klasifikasi pada tabel 2.

Tabel 2. Skema Klasifikasi

\begin{tabular}{|c|c|c|c|}
\hline $\begin{array}{ll}1 & \text { Perkotaan atau } \\
\text { lahan terbangun }\end{array}$ & 11 Permukiman & $\begin{array}{l}111 \text { Bangunan } \\
\text { permukiman yang } \\
\text { ditempati satu } \\
\text { keluarga }\end{array}$ & $\begin{array}{l}1111 \text { Rumah, Rumah-kapal, gubuk, } \\
\text { tenda } \\
1112 \text { Rumah berjalan }\end{array}$ \\
\hline & & $\begin{array}{l}112 \text { Bangunan } \\
\text { permukiman yang } \\
\text { ditempati lebih } \\
\text { dari satu keluarga }\end{array}$ & $\begin{array}{l}1121 \text { Apartemen flat dengan dua } \\
\text { tingkat } \\
1122 \text { Apartemen flat dengan tiga } \\
\text { tingkat } \\
1123 \text { Kondominium / kompleks } \\
\text { apartemen } \\
1124 \text { Trailer rumah berjalan }\end{array}$ \\
\hline & $\begin{array}{l}12 \text { Perdagangan dan } \\
\text { jasa }\end{array}$ & 121 Perdagangan & $\begin{array}{l}\text { 1211 Otomotif } \\
1212 \text { Kapal } \\
1213 \text { Toko serba ada } \\
1214 \text { Finansial dan konstruksi } \\
1215 \text { Makanan dan Obat obatan } \\
\text { 1216 Pemakaman }\end{array}$ \\
\hline
\end{tabular}




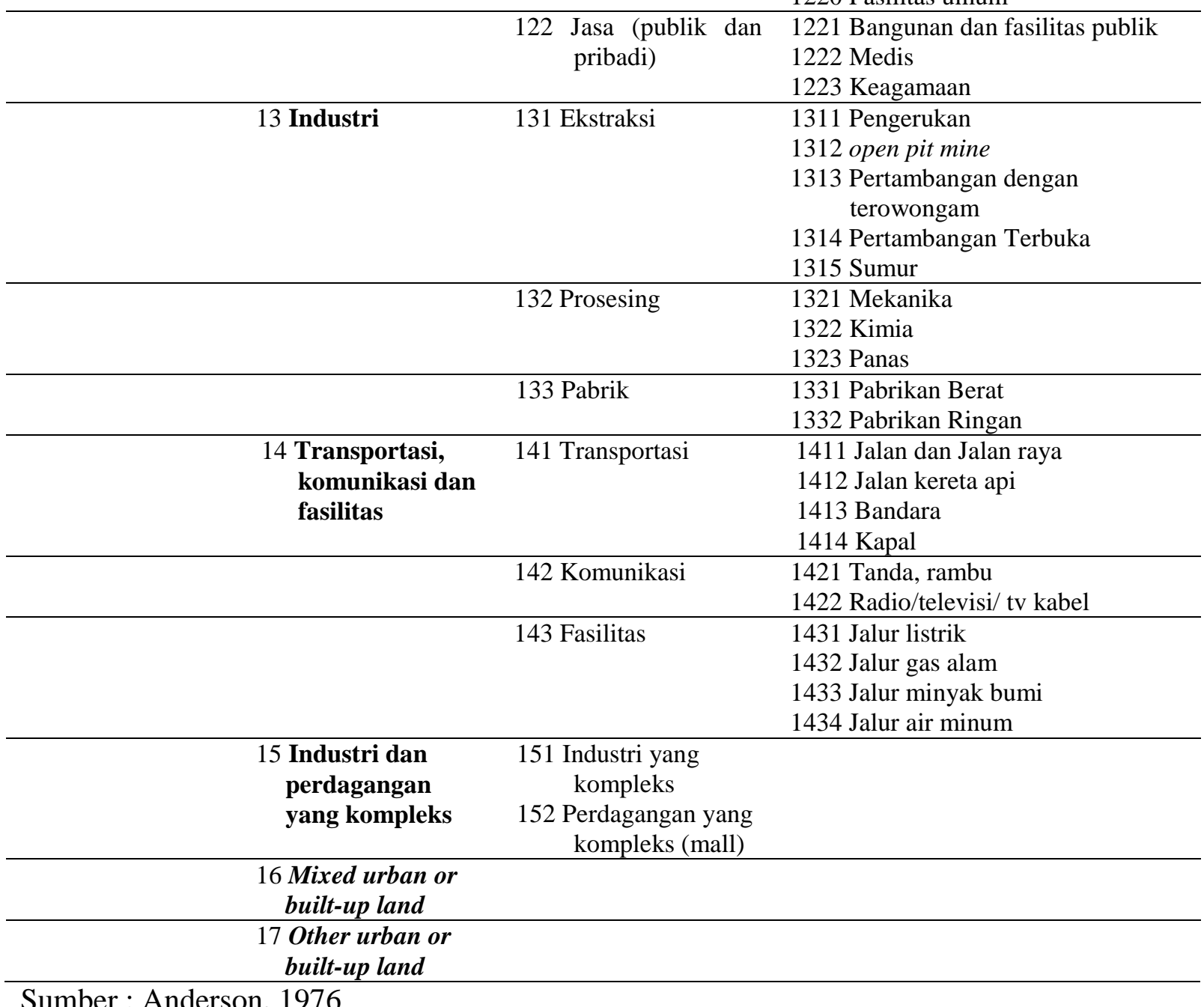

Sumber : Anderson, 1976

Objek-objek yang mudah dikenali di lapangan pada umumnya adalah bangunan yang berukuran besar, terpisah dari bangunan lainnya serta memiliki identitas khusus. Obyekobyek tersebut sebagai berikut.

Permukiman pola teratur, adalah sekelompok rumah yang mempunyai kesamaan dalam bentuk dan ukuran. Dapat dikenali dari atap bangunan berbentuk segi empat dan seragam, ukuran relatif kecil, rona kelabu sampai cerah dan berasosiasi dengan tanaman pekarangan di sekitarnya, tekstur agak kasar, pola teratur, tiap-tiap rumah menghadap ke jalan, terdapat jaringan jalan yang teratur.

Permukiman pola tidak teratur, adalah sekumpulan rumah dengan bentuk dan ukuran serta jarak antar rumah tidak sama. Pada foto udara dicirikan dengan rona kelabu sampai cerah, tekstur kasar, terdapat jaringan jalan yang tidak teratur dan memiliki rona lebih cerah dibandingkan rona atap bangunan.

Pabrik, dikenali pada foto udara dari jumlah bangunan yang lebih dari satu dalam satu kompleks, ukuran masing-masing bangunan besar, bentuk empat persegi panjang, rona kelabu hingga agak cerah, tekstur kasar, mempunyai halaman luas, letak bangunan tidak jauh dari jalan besar, terdapat pagar pembatas bangunan.

Gudang, dicirikan dari ukuran bangunan yang tinggi dan besar, bentuk empat persegi panjang, terdapat jalan masuk yang lebar sehingga dapat dilalui kendaraan besar, terletak di tepi jalan atau di dalam kompleks indsutri. 
Perkantoran, selain yang berukuran besar dan membentuk kompleks perkantoran penggunaan lahan jenis ini sulit dikenali. Kenampakan pada foto udara umumnya dicirikan dari bentuk segi empat, jumlah bangunan biasanya lebi dari satu, rona agak cerah, memiliki halaman di bagian depan yang berfungsi sebagai tempat parkir kendaran.

Pasar, dicirikan oleh keseragaman bangunan yang mencerminkan bangunan los pasar, rona cerah, letak dipinggir jalan besar, terdapat tempat parkir yang luas.

Pertokoan, memiliki ukuran yang lebih besar dari bangunan permukiman di sekitarnya, terletak di sepanjang pinggir jalan, terdiri dari beberapa bangunan dengan ukuran yang bervariasi.

Perguruan tinggi, pada foto udara selain yang membentuk satu kompleks bangunan perguruan tinggi agak sulit dikenali ciri-cirinya, karena kenampakannya menyrupai sekolah ataupun perkantoran. Umumnya bangunan berukuran besar dan lebih dari satu, terdapat jalan masuk cukup lebar, halaman luas di antara bangunan sebagai taman ataupun tempat parkir, biasanya berasosiasi dengan lapangan olahraga, terletak di pinggir jalan besar.

Sekolah, dapat dikenali dari bentuk bangunan segi empat memanjang, menyiku, ataupun membentuk huruf U. Sekolah biasanya beraosiasi dengan lapangan olahraga, memiliki taman, dikelilingi pagar, dekat dengan jalan.

Rumah Sakit, dapat dikenali pada foto udara dari jumlah bangunan yang banyak dan bangunan yang besar, menempati lokasi yang luas, ukuran bangunan bervariasi dengan satu atau lebih bangunan besar, atap berona cerah, terdapat jarak antar bangunan utama dan dihubungkan dengan bangunan memanjang, terdapat taman di antara bangunan, halaman parkir yang luas di bagian depan, terltak di tepi jalan besar.

Masjid, dicirikan dengan ukuran bangunan relative besar, berbentuk bujur sangkar, terdapat kubah bulat ditengahnya, terdapat halaman depan yang luas, dekat dengan permukiman.

Gereja, dapat dikenali dari ukuran bangunan yang besar dan tinggi, terdapat kubah runcing dan tinggi, terletak di tepi jalan, dekat dengan permukiman.

Stasiun kereta api, pada foto udara pankromatik hitam putih dapat dicirikan dari bentuk bangunan segi empat memanjang, terdapat rangkaian gerbong kereta api, terdapat jalur-jalur kereta api yang bercabang pada salah satu sisi dan bergabung lagi pada sisi lain, dekat dengan jalan besar.

Terminal bus, dikenali dari adanya pengelompokkan jenis kendaraan tertentu (bus, colt) dalam deretan berjajar, halaman parkir kendaraan yang luas, terdapat jalan untuk keluar masuk kendaraan dan dekat dengan jalan raya.

Stadion, memiliki ciri-ciri yang spesifik yaitu bentuk bangunan segi empat dengan sudut-sudutnya yang membulat, terdapat lapangan olahraga di bagian tengah bangunan, ukuran bangunan lebih besar dari lapangan olahraga, terdapat pagar tembok yang mengelilingi lapangan, terdapat halaman parker di bagian depan.

Gedung olahraga, umumnya memiliki ukuran yang besar, biasa menyatu dengan fasilitas olahraga lainnya misalnya kolam renang, berona cerah, terdapat halaman parker di bagian depannya, dekat dengan jalan besar.

Lapangan olahraga, kenampakannya tampak menonjol sekali pada foto udara. Dikenali dari cirinya berupa rona yang cerah, bentuk segi empat, tekstur halus, menyatu dengan kompleks sekolah atau daerah permukiman, untuk berukuran besar (lapangan sepakbola) biasanya terletak di pinggir jalan.

Sawah, pada foto udara dapat dikenali dari bentuknya yang khas yaitu berupa petakpetak kecil segi empat. Setiap petak tadi dapat dibedakan satu dengan lainnya karena perbedaan rona yang disebabkan oleh kondisi tanaman padi atau kandungan air pada petak bersangkutan, umumnya berona kelabu gelap hinga angka cerah.

Tegalan, pada foto udara dapat dikenali dari rona agak cerah, tekstur kasar karena tinggi tanaman yang relatif bervariasi, berasoasiasi dengan lahan persawahan. 
Kuburan, dikenali pada foto udara mempunyai rona kelabu hingga cerah yang disebabkan oleh pantulan dari batu nisan, vegetasi, dan tanah di sekitarnya. Arah bangunan seragam (utara - selatan), tekstur kasar, pola tidak teratur, berasosiasi dengan tanaman dekat dan dengan kompleks permukiman.

Berdasarkan penggunaan lahan tersebut kemudian dikelompokkan menjadi 4 klasifikasi seperti pada tabel 3 .

Tabel 3. Klasifikasi dan harkat penggunaan lahan

\begin{tabular}{cccc}
\hline No & Penggunaan Lahan & Kelas & Harkat \\
\hline 1 & Perdagangan dan Jasa & I & 4 \\
\hline 2 & Permukiman dan Industri & II & 3 \\
\hline 3 & Lahan Kosong & III & 2 \\
\hline 4 & Sawah dan tegalan & IV & 1 \\
\hline
\end{tabular}

Sumber : Agustina, 2011

\section{Aksesibilitas Lahan Positif}

Aksesibilitas lahan positif berarti bahwa daerah-daerah yang terletak disekitar jalan ini mempunyai nilai lahan yang lebih tinggi dibandingkan dengan daerah yang lebih jauh dibandingkan dengan beberapa penggunaan lahan yang tergabung dalam aksesibilitas lahan positif. Adapun parameter yang termasuk dalam aksesibilitas lahan positif seperti pada tabel 4.

Tabel 4. Klasifikasi dan harkat aksesilibilitas lahan positif

\begin{tabular}{|c|c|c|c|c|}
\hline No & Aksesibilitas Lahan Positif & Kriteria (m) & Kelas & Harkat \\
\hline \multirow{4}{*}{1} & \multirow{4}{*}{ Jarak terhadap jalan arteri } & $<50$ & I & 4 \\
\hline & & $50-150$ & II & 3 \\
\hline & & $150-500$ & III & 2 \\
\hline & & $>500$ & IV & 1 \\
\hline \multirow{4}{*}{2} & \multirow{4}{*}{ Jarak terhadap jalan kolektor } & $<50$ & I & 4 \\
\hline & & $50-150$ & II & 3 \\
\hline & & $150-500$ & III & 2 \\
\hline & & $>500$ & IV & 1 \\
\hline \multirow{4}{*}{3} & \multirow{4}{*}{ Jarak terhadap Jalan Lokal } & $<50$ & $\mathrm{I}$ & 4 \\
\hline & & $50-150$ & II & 3 \\
\hline & & $150-500$ & III & 2 \\
\hline & & $>500$ & IV & 1 \\
\hline \multirow{3}{*}{4} & \multirow{3}{*}{$\begin{array}{l}\text { Jarak terhadap lembaga } \\
\text { pendidikan }\end{array}$} & $<200$ & I & 3 \\
\hline & & $200-500$ & II & 2 \\
\hline & & $>500$ & III & 1 \\
\hline \multirow{3}{*}{5} & \multirow{3}{*}{$\begin{array}{c}\text { Jarak terhadap kantor } \\
\text { pemerintahan }\end{array}$} & $<200$ & I & 3 \\
\hline & & $200-500$ & II & 2 \\
\hline & & $>500$ & III & 1 \\
\hline
\end{tabular}

Sumber : Meyliana (1996)

\section{Aksesibilitas Lahan Negatif}

Variabel yang termasuk dalam aksesibilitas lahan negatif merupakan variabel yang menurunkan harga lahan, diantaranya sungai, kuburan, sumber polusi, sampah, pembuangan limbah, dan sebagainya. Adapun pengharkatan untuk aksesibilitas lahan negatif seperti pada tabel 5 .

Tabel 5. Klasifikasi dan harkat aksesilibilitas lahan positif 


\begin{tabular}{llccc}
\hline No & Aksesibilitas Lahan Negatif & Kriteria $(\mathrm{m})$ & Kelas & Harkat \\
\hline 1 & Jarak terhadap sungai & $<200$ & I & 2 \\
& & $>200$ & II & 1 \\
\hline 2 & Jarak terhadap sumber polusi & $<200$ & I & 2 \\
& & $>200$ & II & 1 \\
\hline 3 & Jarak terhadap kuburan & $<200$ & I & 2 \\
& & $>200$ & II & 1 \\
\hline
\end{tabular}

Sumber : Meyliana, 1996

\section{Kelengkapan fasilitas Umum}

Fasilitas umum merupakan salah satu parameter yang menjadikan harga lahan itu semakin tinggi. Keberadaan fasilitas kesehatan dan pendidikan ataupun fasilitas ekonomi menjadi incaran bagi warga masyarakat untuk menjual maupun membeli lahan dengan harga yang lebih variatif. Sehingga dalam penelitian ini kelengkapan fasilitas kota menjadi salah satu parameter yang digunakan dalam perhitungan harga lahan. Kelengkapan fasilitas umum ini dihitung berdasarkan jumlah kelengkapan fasilitas per satuan wilayah. Hal ini dikenal dengan nama intensitas kelengkapan fasilitas umum. Rumus untuk menghitung kelengkapan fasilitas umum adalah sebagai berikut:

$$
\text { Intensitas Kelengkapan Umum }=\frac{\text { Jumlah Kelengkapan fasilitas umum }}{\text { Luas Wilayah Kelurahan }}
$$

Analisis tumpang susun dilakukan dalam penelitian ini untuk memperoleh hasil sementara sebelum dilakukan cek lapangan. Data atribut hasil overlay tersebut kemudian dikalikan berdasarkan faktor pembobot dari setiap parameter penentu harga lahn seperti yang tertuang pada tabel 6 .

Tabel 6. Nilai Bobot Faktor Penentu Harga Lahan

\begin{tabular}{clc}
\hline No & \multicolumn{1}{c}{ Faktor Penentu Harga Lahan } & Nilai Bobot \\
\hline 1 & Penggunaan Lahan & 3 \\
\hline 2 & Aksesibilitas Lahan Positif & 2 \\
\hline 3 & Aksesibilitas Lahan Negatif & -1 \\
\hline 4 & Kelengkapan Fasilitas Umum & 1 \\
\hline
\end{tabular}

Total harkat penentu harga lahan diperoleh dari perkalian dan penjumlahan nilai harkat penentu harga lahan dengan faktor pembobot menggunakan formula sebagai berikut:

$$
\begin{aligned}
& \text { Nilai Harga Lahan } \\
& \qquad \begin{array}{l}
=3 * P L+2 * \text { aks lahan positif }+ \text { Fslts Umum } \\
- \text { Aksesibilitas Lahan Negatif }
\end{array}
\end{aligned}
$$

\section{HASIL PEMBAHASAN \\ Deskripsi Wilayah Penelitian}

Kecamatan Jetis secara geografis terletak antara $7^{\circ} 21^{\prime} 18^{\prime \prime}$ sampai $7^{\circ} 22^{\prime} 17^{\prime \prime}$ dengan luas wilayah 1,7 ha dan dilalui oleh Sungai WInongo dan Sungai Code. Secara administrasi Kecamatan Jetis dibatasi oleh sebelah utara adalah Kecamatan Tegalrejo, sebelah selatan Kecamatan Gedongtengen dan Kecamatan Danurejan, sebelah timur berbatasan dengan Kecamatan Gondokusuman, dan sebelah barat berbatasan dengan Kecamatan Tegalrejo. Secara administrasi Kecamatan Jetis terdiri dari 3 kelurahan yaitu Kelurahan Bumijo, Kelurahan Gowongan, dan Kelurahan Cokrodiningratan. 
Wilayah Kecamatan Jetis dilihat dari topografinya merupakan daerah datar dengan ketinggian $115 \mathrm{~m}$ dpal. Pada tahun 2010 jumlah penduduk di Kecamatan Jetis sebanyak 39.164 jiwa dan mempunyai penambahan penduduk sebanyak 179 jiwa pertahun.

\section{Interpretasi Penggunaan Lahan}

Berdasarkan citra Quickbird Kecamatan Jetis dapat diketahui bahwa di kecamatan tersebut terdapat pada tabel 7 .

Tabel 7. Penggunaan Lahan di Kecamatan Jetis

\begin{tabular}{lcc}
\hline Pengunaan Lahan & $\begin{array}{c}\text { Luas } \\
(\mathrm{km} 2)\end{array}$ & $\begin{array}{c}\text { Persentase } \\
(\%)\end{array}$ \\
\hline Permukiman & 0,51 & 30,04 \\
\hline Pertokoan & 0,49 & 28,86 \\
\hline Bank & 0,09 & 5,30 \\
\hline Hotel & 0,09 & 5,30 \\
\hline Perkantoran & 0,12 & 7,07 \\
\hline Kuburan & 0,009 & 0,53 \\
\hline Lahan Kosong & 0,07 & 4,12 \\
\hline Lapangan & 0,009 & 0,53 \\
\hline Pabrik & 0,005 & 0,29 \\
\hline Pasar & 0,046 & 2,71 \\
\hline SPBU & 0,12 & 7,07 \\
\hline Sekolah & 0,012 & 0,71 \\
\hline Taman & 0,05 & 2,94 \\
\hline Tempat Ibadah & 0,006 & 0,35 \\
\hline Universitas & 0,07 & 4,12 \\
\hline Vegetasi & 0,001 & 0,06 \\
\hline Luas & 1,698 & 100,00 \\
\hline
\end{tabular}

Penggunaan lahan tentunya sangat berpengaruh terhadap harga lahan. Sebagai contoh, penggunaan lahan hotel dan fasilitas pendidikan akan sangat mempengaruhi tinggi harga lahan. Keberadaan hotel juga sangat berpengaruh terhadap harga lahan di perkotaan. Adapun hasil identifikasi penggunaan lahan tertera sebagaimana dalam tabel 7. Distribusi spasial untuk penggunaan lahan tersaji pada gambar 1. 


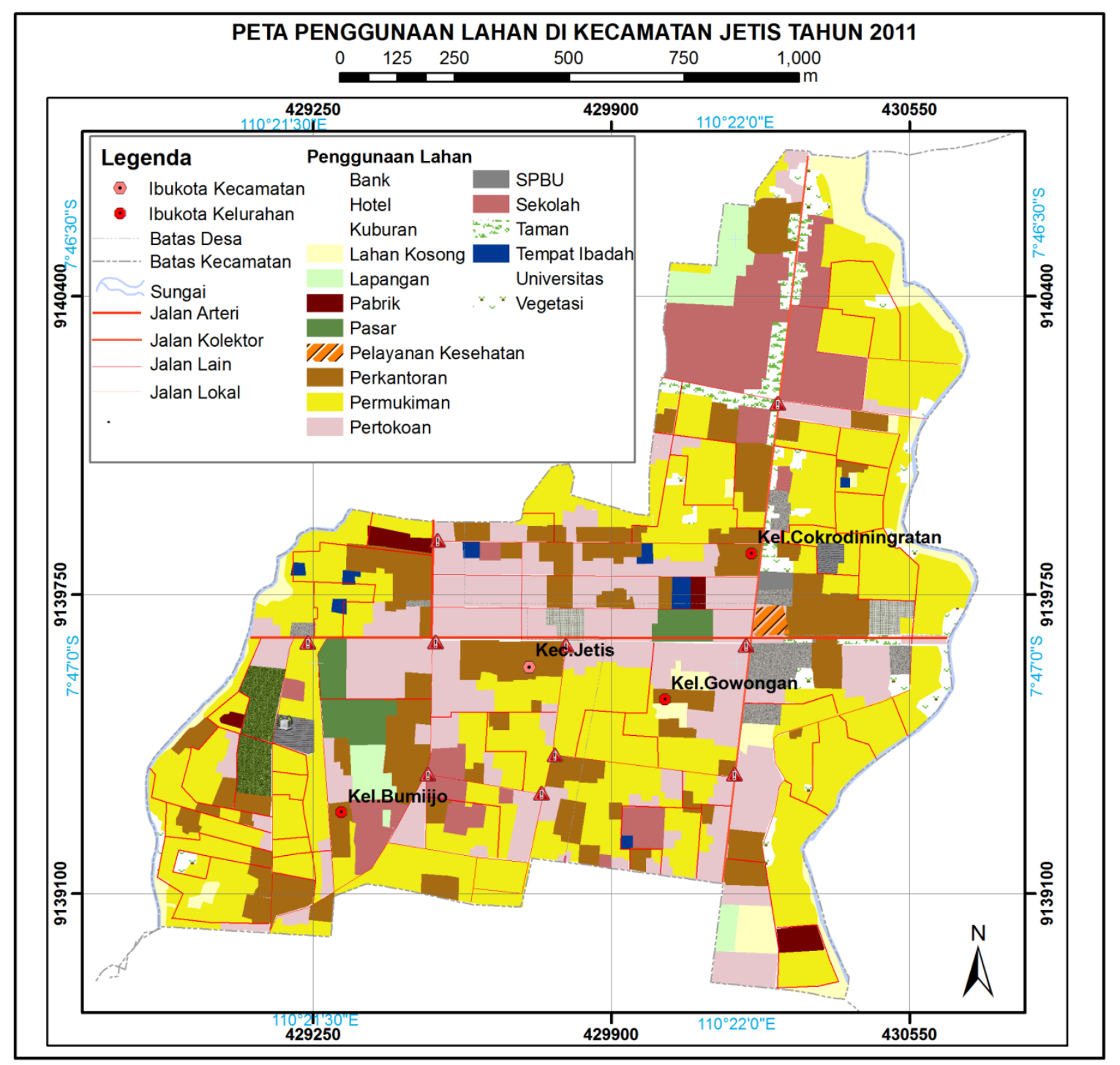

Gambar 1. Peta Penggunaan Lahan Kecamatan Jetis Tahun 2011

\section{Uji Ketelitian Interpretasi Penggunaan Lahan}

Matriks kesalahan membandingkan kategori per kategori (kelas per kelas) hubungan antara data sebenarnya (ground truth) atau data lapangan dengan data hasil klasifikasi otomatis. Hasil interpretasi ini selanjutnya dapat digunakan untuk melakukan uji ketelitian data penggunaan lahan berdasarkan atas kenyataan yang ada sekarang di lapangan, pengujian ketelitian yang dilakukan adalah untuk mengetahui ketelitian secara semantik dengan menggunakan tabel matrik dua dimensi. Untuk penelitian pada kali ini hasil uji interpretasi menunjukkan ketelitian interpretasi sebesar 92,49\%.

\section{Re-Interpretasi Peta Penggunaan Lahan di Kecamatan Jetis}

Setelah melakukan uji ketelitian interpretasi di lapangan, hal selanjutnya yang dilakukan adalah melakukan klasifikasi ulang atau re-interpretasi peta penggunaan lahan tentatif. Hasil dari re-interpretasi peta ini selanjutnya digunakan sebagai salah satu parameter untuk pembobotan. Penggunaan lahan mempunyai pembobotan paling tinggi jika dibandingkan dengan parameter-parameter yang lain.

Penggunaan lahan yang mendominasi penggunaan lahan di Kecamatan Jetis adalah penggunaan lahan permukiman seluas $0,51 \mathrm{~km}^{2}$ atau $30 \%$ dari seluruh penggunaan lahan yang ada, penggunaan lahan selanjutnya adalah penggunaan lahan pertokoan seluas 0,49 $\mathrm{km}^{2}$ dengan persentase $28,82 \%$ dan penggunaan lahan yang memiliki persentase terendah 
adalah penggunaan lahan SPBU sebesar 0,08\%. Luas keseluruhan dari penggunaan lahan Kecamatan Jetis sebesar $1,70 \mathrm{~km} 2$. Luas dan persentase penggunaan lahan di Kecamatan Jetis. Hasil pemetaan penggunaan lahan terlihat dalam gambar 2.

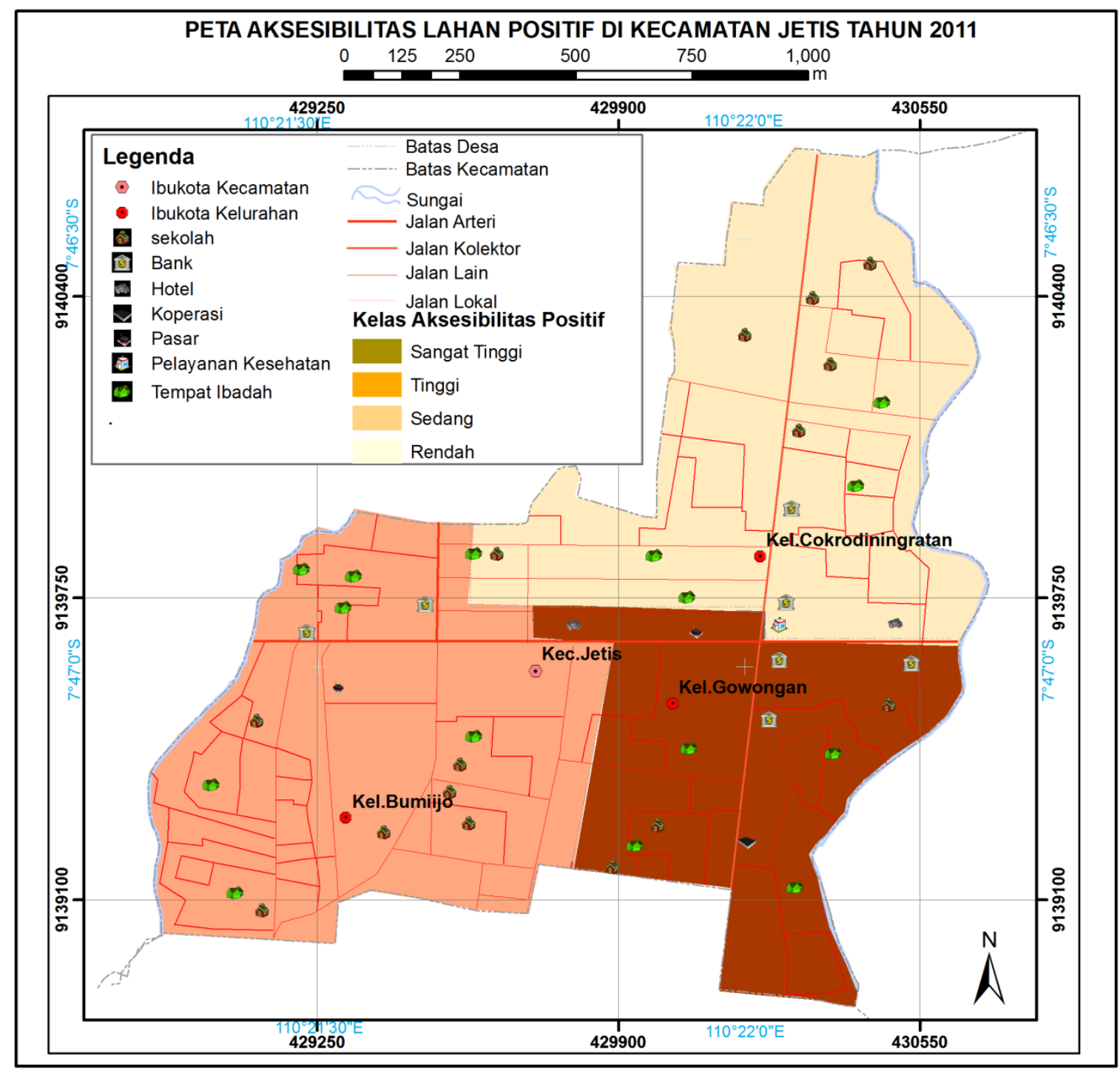

Gambar 2. Peta Aksesibilitas Lahan Positif

Aksesibilitas Lahan Positif

Aksesibilitas lahan positif merupakan lahan yang mendukung untuk penjualan harga lahan semakin tinggi. Aksesibilitas lahan positif ini juga memberikan kemudahan bagi orangorang dalam bergerak menjalankan aktivitas sehari-harinya. Orang-orang akan cenderung memilih lahan yang mempunyai fasilitas banyak seperti rumah sakit, fasilitas pendidikan, sarana peribadatan, perekonomian, dan sebagainya. Untuk perhitungan aksesibilitas lahan positif dalam hal ini adalah menggunakan metode buffering untuk masing-masing lahan yang mempunyai aksesibilitas lahan positif. Hasil dari perhitungan menunjukkan bahwa aksesibilitas lahan positif terbagi menjadi empat kelas yaitu kelas I dengan skor 15,1 - 17,0; kelas II dengan skor 13,1 - 15,0; kelas III dengan nilai 11,1 - 13,0, dan kelas IV dengan sekor 9,1 - 11,0. Daerah pada aksesbilitas lahan positif kelas I ini merupakan daerah yang sangat strategis karena letaknya dekat jalan kolektor dan arteri dan juga merupakan daerah yang masuk dalam kawasan perdagangan dan jasa, di mana letaknya dekat dengan pusat pemerintahan dan juga fasilitas pendidikan. Lahan pada aksesbilitas lahan positif kelas I ini memiliki nilai lahan yang sangat tinggi. Aksesbilitas lahan positif kelas II (tinggi) masih terdapat di sekitar pinggir jalan kolektor dan arteri pada sebagian kecil Kelurahan Gowongan 
dan Cokrodiningratan. Karena letaknya yang cukup strategis, lahan pada aksesbilitas lahan positif kelas II ini merupakan lahan yang banyak di cari orang sehingga harga lahannya tinggi. Dari hasil penelitian dapat digambarkan dalam tabel 8 dan pemetaan aksesibilitas lahan positif digambarkan pada gambar 3.

Tabel 8. Luas dan Persentase Aksesibilitas Lahan Positif

\begin{tabular}{lcc}
\hline Aksesibilitas Lahan Positif & $\begin{array}{c}\text { Luas } \\
(\mathrm{km} 2)\end{array}$ & $\begin{array}{c}\text { Persentase } \\
(\%)\end{array}$ \\
\hline Sangat Tinggi & 0,06 & 352 \\
\hline Tinggi & 0,31 & 18,24 \\
\hline Sedang & 0,46 & 27,06 \\
\hline Rendah & 0,87 & 51,18 \\
\hline Jumlah & 1,70 & 100 \\
\hline
\end{tabular}

Sumber : Analisis 2011

\section{Aksesibilitas Lahan Negatif}

Aksesbilitas negatif merupakan segala sesuatu yang bernilai negatif, seperti sungai, kuburan dan sumber polusi yang merupakan faktor penyebab berkurangnya nilai lahan. Orang-orang berasumsi bahwa lahan yang terletak dekat dengan aksesbilitas lahan negatif merupakan lahan yang tidak menguntungkan bahkan merugikan, karena lahan yang letaknya dekat dengan sungai kemungkinan besar lahan tersebut akan tergenang banjir pada saat musim hujan ataupun lahan yang letaknya dekat dengan sumber polusi akan menyebabkan pencemaran udara dan kebisingan yang membuat kenyamanan menjadi terganggu, sehingga harga lahannya menjadi rendah. Peta aksesbilitas lahan negatif di buat dari hasil overlay buffer sungai, kuburan dan sumber polusi. Dari hasil perhitungan analisis data atribut, peta aksesbilitas lahan negatif terbagi kedalam dua kelas, yaitu kelas aksesbilitas lahan negatif sedang dan kelas aksesbilitas lahan negatif rendah. Perhitungan dan analisis aksesibilitas lahan negatif untuk Kecamatan Jetis dapat dilihat dalam tabel 9 dan distribusi spasial aksesibilitas lahan negatif tertuang dalam gambar 3 .

Tabel 9. Luas dan Persentase Aksesibilitas Lahan Negatif

\begin{tabular}{lcc}
\hline Aksesibilitas Lahan Negatif & $\begin{array}{c}\text { Luas } \\
(\mathrm{km} 2)\end{array}$ & $\begin{array}{c}\text { Persentase } \\
(\%)\end{array}$ \\
\hline Sangat Tinggi & 0,19 & 11,18 \\
Sedang & 1,51 & 88,82 \\
Rendah & 1,70 & 100 \\
Jumlah & &
\end{tabular}

Sumber : Analisis 2011 


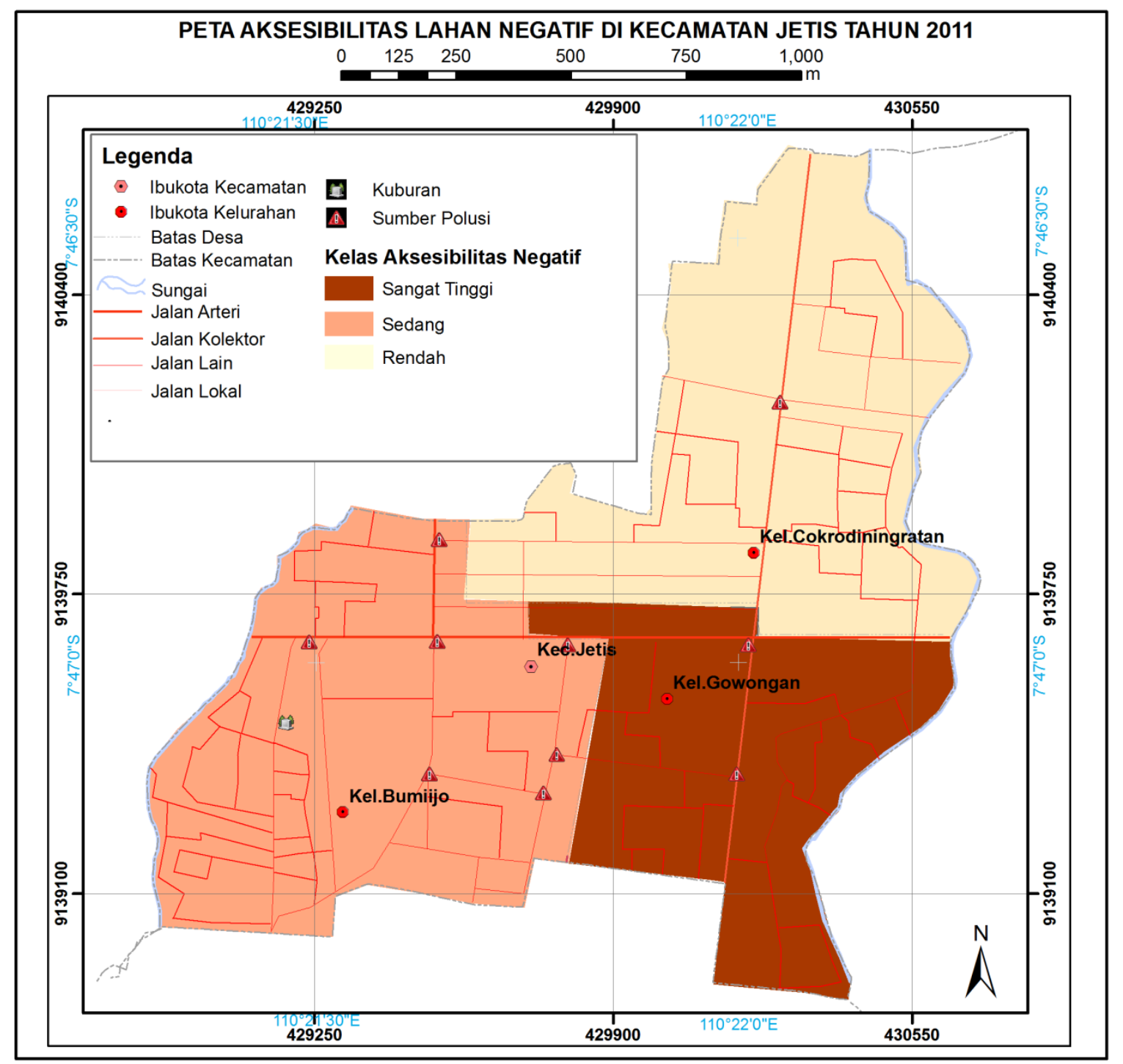

Gambar 3.Peta Aksesibilitas Lahan Negatif

\section{Data Kelengkapan Fasilitas Umum}

Kelengkapan fasilitas umum di nilai berdasarkan sarana penunjang untuk pelayanan lingkungan yang terdiri dari beberapa fasilitas yang di butuhkan oleh masyarakat dan berpengaruh terhadap perkembangan wilayah di sekitarnya, di mana semakin lengkap dan baik fasilitas yang mendukung berbagai kegiatan dan kebutuhan masyarakat akan mempertinggi harga lahan di wilayah tersebut dan mempengaruhi penduduk untuk memilih lahan tersebut sebagai sarana tempat tinggal atau lainnya. Data kelengkapan fasilitas umum yang digunakan untuk membuat peta kelengkapan fasilitas umum berupa data sekunder yang di dapat dari Badan Pusat Statistik (BPS) Kota Yogyakarta. Data kelengkapan fasilitas umum berupa data jumlah bank pemerintah dan swasta, pasar umum, tempat ibadah, fasilitas kesehatan,swalayan, koperasi, hotel dan wartel. Fasilitas umum dapat di kaitkan dengan aksesbilitas lahan positif. Daerah yang memiliki kelengkapan fasilitas umum tinggi akan memiliki aksesbilitas lahan positif yang tinggi pula. Hal ini di karenakan fasilitas umum biasanya terletak pada daerah stategis yang dapat di jangkau dengan mudah dan biasanya terletak dekat dengan jalan arteri maupun kolektor. Tabel di bawah ini menunjukan intensitas kelengkapan fasilitas umum Kecamatan Jetis di rinci tiap Kelurahan. 
Tabel 10. Luas dan Persentase Aksesibilitas Lahan Negatif

\begin{tabular}{lccc}
\hline Kelurahan & $\begin{array}{c}\text { Luas } \\
(\mathrm{km} 2)\end{array}$ & $\begin{array}{c}\text { Jumlah Kelengkapan } \\
\text { Fasilitas Umum }\end{array}$ & $\begin{array}{c}\text { Intensitas Kelengkapan } \\
\text { Fasilitas Umum }\end{array}$ \\
\hline Bumijo & 0,58 & 48 & 82,758 \\
Gowongan & 0,46 & 51 & 110,869 \\
Cokrodiningratan & 0,66 & 42 & 63,636 \\
\hline Sur : Antising
\end{tabular}

Sumber : Analisis 2011

\section{Peta Kelas Harga Lahan}

Peta kelas harga lahan merupakan peta hasil analisis data atribut overlay beberapa peta parameter penentu harga lahan, yaitu : peta penggunaan lahan, peta aksesbilitas lahan positif, peta aksesbilitas lahan negatif dan peta kelengkapan utilitas umum. Dari hasilperhitungan dan analisis total harkat semua parameter penentu harga lahan didapat empat kelas harga lahan, yaitu: kelas I dengan tingkat harga lahan sangattinggi, kelas II dengan tingkat harga lahan tinggi, kelas III tingkat harga lahansedang dan kelas IV dengan tingkat harga lahan rendah.

Harga lahan kelas I (sangat tinggi) memiliki nilai lahan yang sangattinggi. Harga lahan kelas I terdapat di sepanjang jalan arteri dan kolektorKelurahan Gowongan dan Cokrodiningratan. Daerah ini merupakan daerahyang memiliki nilai lahan yang tinggi karena letaknya yang strategis,aksesbilitas lahan positifnya tinggi, fasilitas umum yang tersedia di daerahini juga lengkap.

Harga lahan kelas II (tinggi) terdapat di sebagian besar Kelurahan Bumijo, Gowongan dan Cokrodiningratan, atau dapat di katakan sebagian besar wilayah Kecamatan Jetis masuk dalam kelas harga lahan II. Hal ini di karenakan Kecamatan Jetis merupakan daerah perkotaan, di mana jenis penggunaan lahan yang mendominasi adalah pertokoan dan permukiman, fasilitas umum yang ada juga sudah lengkap.

Harga lahan kelas III (sedang) memiliki aksesbilitas lahan negatif rendah. Walaupun memiliki aksesbilitas lahan negatif yang rendah, namun lahan pada harga lahan kelas III ini memiliki nilai lahan rendah karena terletak dekat dengan sungai maupun kuburan. Jenis penggunaan lahan yang ada pada harga lahan kelas III ini adalah permukiman, aksesbilitas lahan positifnya sedang di mana hanya di lalui oleh jalan lokal dan jalan lain saja. Fasilitas umum yang tersediapun termasuk kedalam kategori rendah atau sedikit.

Harga lahan kelas IV (rendah) memiliki nilai lahan yang rendah. Lokasinya sangat dekat dengan sungai maupun kuburan, aksesbilitas lahan positifnya rendah dan tidak adanya fasilitas umum yang tersedia. Jenis penggunaan lahan yang ada berupa permukiman dan lahan kosong.

\section{Analisis Harga Lahan}

Dari hasil penelitian yang ada harga lahan sangat tinggi terdapat di Kelurahan Gowongan dan Cokrodiningratan dan sebagian kecil di Kelurahan Bumijo yang terletak di sepanjang jalan arteri dan kolektor. Survey lapangan juga menunjukkan bahwa rerata harga lahan di daerah tersebut adalah Rp 6.000.000,00 - Rp 7.000.000,00. Sedangkan harga lahan tinggi terdapat di Kecamatan Jetis yang sebagian besar wilayahnya mempunyai aksesibilitas lahan positif yang baik. Range harga lahan untuk daerah ini sebesar Rp 3.000.000,00 - Rp $5.000 .000,00 / \mathrm{m} 2$. Harga lahan rendah terdapat pada lahan yang mempunyai aksesibilitas negatif tinggi, mempunyai lokasi yang tidak terlalu strategis, dekat dengan kuburan maupun sungai, jauh dari perkantoran pemerintah dan sebagian besar penggunaan lahan berupa lahan kosong. Harga untuk lahan rendah ini berkisar antara Rp 500.000,00 - Rp 800.000,00/m2. 


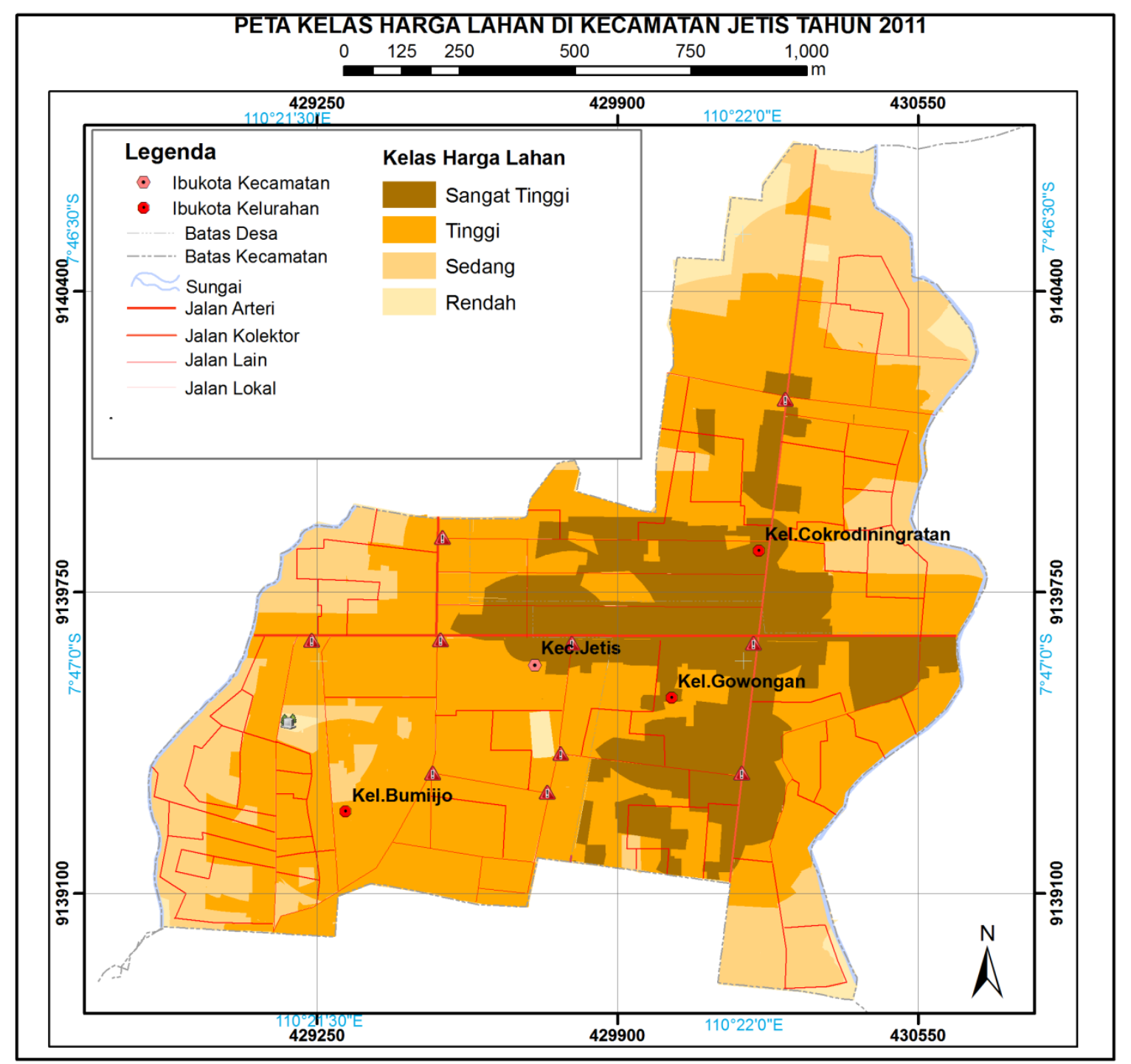

Gambar 4. Peta Kelas Harga Lahan

\section{SIMPULAN}

Kesimpulan dari penelitian ini adalah 1) Citra Quickbird dapat memberikan informasi yang baik untuk interpretasi harga lahan dengan uji ketelitan sebesar 92,39\%; 2). Hasil dari penelitian ini menyebutkan bahwa di Kecamatan Jetis terbagi menjadi beberapa kelas harga lahan yaitu harga lahan tinggi dengan persentase 52,35\%, harga lahan tinggi sebesar 22,94\%, harga lahan sedang dan harga lahan paling rendah.

\section{DAFTAR PUSTAKA}

Badan Pemetaan Daerah. 2011. Deskripsi Wilayah Kota Yogyakarta. Yogyakarta Badan Pusat Statistik. 2011. Kota Yogyakarta dalam Angka 2011. Yogyakarta

Ghani.2008. Pemetaan Persebaran NJOP Kabupaten Pati.Laporan Penelitian. Fakultas Geografi Universitas Gadjah Mada. Yogyakarta.

Damayanti, Ika Abrita. 2008. Pemanfaatan Citra IKONOS dan Sistem Informasi Geografi Dalam Rangka Pemetaan Estimasi Harga Lahan di Kecamatan Danurejan Kota Yogyakarta.Tugas Akhir. Fakultas Geografi Universitas Gadjah Mada. Yogyakarta.

Hidayati, Iswari Nur. 2010. Modul Penginderaan Jauh untuk Studi Perkotaan. Fakultas Geografi. UGM

Meirani Fitrianingsih. 2011. Analisis Pengarih Harga Sewa, Pendapatan Keluarga, Fasilitas, Lokasi, dan Harga Substitusi terhadap Permintaan Rusunawa. Universitas Diponegoro. 
Meyliana.1996. Penerapan Penginderaan Jauh dan Sistem Informasi Geografi Untuk Mengkaji Harga Lahan di Kecamatan Laweyan Kotamadya Surakarta.Skripsi. Fakultas Geografi Universitas Gadjah Mada. Yogyakarta.

Setyawan, Dony. 2009. Studi Komparatif Harga Lahan Berdasarkan Nilai Jual Objek Pajak (NJOP) Bumi dan Harga Pasaran Dalam Perspektif Keruangan Kota Yogyakarta.Skripsi. Fakultas Geografi Universitas Gadjah Mada. Yogyakarta.

Singgih, Doddy S. 1999. Metode Analisis Fungsi Lahan dalam Perspektif Sosiologi Pedesaan.Journal.Masyarakat Kebudayaan dan Politik. Th XII, No. 3. Juli 1999.1-8.

Susanti, Diyah Reny. 2004. Penggunaan Ortofoto Untuk Invetarisasi Harga Lahan ( Kasus di Kecamatan Ngaglik Kabupaten Sleman). Skripsi. Fakultas Geografi Universitas Gadjah Mada. Yogyakarta.

Sutawijaya, Adrian. 2004. Analisis Faktor-faktor yang mempengaruhi Nilai Tanah sebagai Dasar Penilaian Nilai Jual Objek Pajak PBB di Kota Semarang.Jurnal.Jurnal Ekonomi Pembangunan Vol.9. No 1.Juni 2004. Kajian Ekonomi Negara Berkembang hal 65-78.

Suryani. 2012. Analisis Bebebrapa Faktor Sosial Ekonomi yang mempengaruhi Pendapatan Usaha Tani. Jurnal. Jurnal Agrista - ISSN 2302-1713. Program Studi Agribisnis. Universitas Sebelas Maret Surakarta. 